\title{
Diversity of Coprinus species in North-Eastern part of Uttar Pradesh, India.
}

Ravinder Pal Singh*, Aradhana Pal, Pooja Singh and N. N. Tripathi

Bacteriology and Natural Pesticide Laboratory,

Department of Botany, DDU Gorakhpur University, Gorakhpur-273009, (U.P.) India.

Received: 4/16/2018; Revised: 4/27/2018; Accepted: 4/30/2018

\begin{abstract}
Gorakhpur is an 'oriental region' providing a profusion of habitats, which features diverse biota with a high level of endemism. The region is an important sub-centre for the origin of mushrooms, the most important among the macrofungi. Studies on the taxonomy and diversity of macrofungi are gaining importance as many macrofungi are becoming extinct and facing threat of extinction because of climate change effects and habitat alteration. The present study was undertaken w.e.f. March 2014 to July 2016 in different localities of Gorakhpur district of Uttar Pradesh, India to collect the samples of macrofungi describing the systemic position and taxonomic identification. This paper deals with the collections of genus Coprinus made from various localities of Gorakhpur and all the collected macrofungal species belonging to the family Coprinaceae. Presently, 14 Coprinus species, viz., Coprinus atramentarius, C. comatus, C. congregates, $C$. disseminates, C. domesticus, C. extinctorius, C. hemerobius, C. heterosetulosus, C. impatiens, C. lagopus, C. leiocephalus, C. micaceus, C. radiates and $C$. truncorum were collected and identified on the basis of their morphological and microscopic characters.
\end{abstract}

Keywords: Macrofungi, Diversity, Coprinus

\section{Introduction}

The species diversity of fungi and their natural beauty occupy primary place in the biological world and India has been a cradle for these species. Defining the number of fungi on earth has been a point of discussion and several studies have focused on enumerate the world's fungal diversity. Only a fraction of total wealth has been subjected to scientific scrutiny and mycologists continue to unravel the unknown and hidden wealth (Vishwakarma et al., 2017). Mushroom is a general term used mainly for the fruiting body of the macrofungi (Ascomycota \& Basidiomycota) and represents only a short reproductive stage in their life cycle. Wild mushrooms have a profound biological and economical impact. They have had a long association with humankind. From ancient times, wild mushrooms have been consumed by man with delicacy probably, for their texture and pleasing flavor (Das, 2010).

Coprinoid macrofungi, also called inky caps, are very interesting mushrooms and are mainly characterized by liquefying gills, at least partially, of the mature fruit bodies. During the liquefying process, which starts from the bottom of the gills and goes up, the shape of the cap changes from more or less oval to broadly bell-shaped or flat, or it peels up substantially (Kaya et al., 2010). The diversity and galaxy of fungi and their natural beauty has prime place in the biological world. Studies on macrofungal diversity have been carried out by several countries, and new species for the world macrofungal flora have continuously been

\footnotetext{
${ }^{*}$ Corresponding Author:

Ravinder Pal Singh,

Bacteriology and Natural Pesticide Laboratory,

Department of Botany, DDU Gorakhpur University,

Gorakhpur-273009, (U.P.), India.

E-mail: ravinder.20033@gmail.com
}

documented from all over the world (Dutta et al., 2012).

The macrofungal diversity is depleting fast due to deforestation, urbanization, climate change and unsystematic exploitation through collection of wild mushrooms. This situation demands an urgent need to collect, document and conserve this group. Most macrofungi are cosmopolitan, occurring both in tropical and temperate regions. They occur seasonally all over the world in various habitats such as humus rich soils, decaying plant litter and wood logs in forests as well as in meadows and even in sandy and other soils. Some species, particularly mycorrhizal mushrooms are on the verge of extinction. Several workers have studied macrofungal diversity of their respective places and recorded their observations in various regions viz., Eastern Himalayas, Kashmir valley; Garhwal; South East Maharashtra of India (Borkar et al., 2015).

During rainy season, there is abundant growth of several kinds of mushroom. The present communication, as part of continuing investigations, describes some macrofungi from Gorakhpur, India.

\section{Materials and Methods}

Collection of mushroom samples

The present study is based on 3 years (2014-2016) periodical field survey among 7 Tehsils viz., Bansgaon, Chauri Chaura, Campierganj, Gola, Khajni, Sadar and Sahjanwa of Gorakhpur district 
during the monsoon season to understand the morphological variability in the mushrooms population. Field samples of macrofungi were collected and brought to laboratory for further studies and preserved in the $4 \%$ formaldehyde solution. Macroscopic morphological details such as size, shape, colour and texture of fresh specimens, were recorded in the field before preservation. Microscopic study was carried out on dry and wet samples, mounted in 5\% $\mathrm{KOH}$, Melzer's reagent, Lactophenol, Congo red and Carbolfuchsin. Macrofungi samples were identified on the basis of macroscopic and microscopic characteristics and confirmed by the relevant literatures (Jordan, 1995) and Mycokey (http:/www.mycokey.com). The samples were deposited in the Departmental herbarium of DDU, Gorakhpur University, Gorakhpur, India.

\section{Results}

The species diversity of Coprinus in this area are listed in Table-1. Total 14 species of Coprinus were collected from different habitat viz., grassland, pasture, roadsides, wooded area, sand dunes, over dead stumps and living trees and identified on the basis of their morphological and microscopic characters. Species of Coprinus viz., Coprinus atramentarius, C. comatus, C. congregatus, $C$. disseminates, $C$. domesticus, $C$. extinctorius, $C$. hemerobius, C. heterosetulosus, C. impatiens, C. lagopus, C. leiocephalus, C. micaceus, $C$. radiates and $C$. truncorum are individually described. The present description agrees with the description given by Jordan (1995).

Table1. Species, family, edibility, habit and habitat of collected samples

\begin{tabular}{|c|c|c|c|c|}
\hline Macrofungi & Family & Habit and habitat & Edibility & $\begin{array}{c}\text { Date of } \\
\text { collection }\end{array}$ \\
\hline C. atramentarius (Bull.: Fr.) Fr. & Coprinaceae & Saprobic, in group on humus rich soil & Edible & $14-07-2014$ \\
\hline C. comatus (O.F. Müll.) Pers. & Coprinaceae & Saprobic, in group on manure & Inedible & $5-01-2015$ \\
\hline C. congregatus Bull.: Fr. & Coprinaceae & Saprobic, solitary to in group on soil & Inedible & $22-08-2015$ \\
\hline C. disseminates (Pers.: Fries) J.E. Lange & Coprinaceae & $\begin{array}{l}\text { Saprobic on rotting tree branch, in } \\
\text { group }\end{array}$ & Inedible & $22-08-2015$ \\
\hline C. domesticus (Bolton) Gray & Coprinaceae & $\begin{array}{l}\text { Saprobic, gregariously in small troops, } \\
\text { on decaying wood log }\end{array}$ & Inedible & $12-08-2015$ \\
\hline C. extinctorius (Bull.) Fr. & Coprinaceae & Saprobic, scattered, on decaying litter & Inedible & $12-08-2014$ \\
\hline C. hemerobius Fr. & Coprinaceae & Saprobic, in group, on decaying litter & Inedible & $25-08-2015$ \\
\hline C. heterosetulosus Locq. ex Watling & Coprinaceae & Saprobic, in group, on decaying litter & Inedible & $22-08-2014$ \\
\hline C. impatiens (Fr.) Quél. & Coprinaceae & Saprobic, scattered, on decaying litter & Inedible & $22-08-2015$ \\
\hline C. lagopus (Fr.) Fr. & Coprinaceae & $\begin{array}{l}\text { Saprobic, solitary to in group on } \\
\text { decaying wood log }\end{array}$ & Inedible & $22-08-2015$ \\
\hline C. leiocephalus P Orton & Coprinaceae & $\begin{array}{l}\text { Saprobic, gregariously in small troops, } \\
\text { on decaying wood log }\end{array}$ & Inedible & $25-08-2015$ \\
\hline C. micaceus Bull.:Fr. & Coprinaceae & $\begin{array}{l}\text { Saprobic, gregariously in small troops, } \\
\text { on decaying wood log }\end{array}$ & Inedible & $22-07-2014$ \\
\hline C. radiates (Bolt.: Fr.) S F Gray & Coprinaceae & $\begin{array}{l}\text { Coprophillus, in group on cow dung } \\
\text { manure }\end{array}$ & Inedible & $12-08-2015$ \\
\hline C. truncorum (Scop.) Fr. & Coprinaceae & $\begin{array}{l}\text { Saprobic, in group on decaying wood } \\
\log \end{array}$ & Inedible & $22-08-2015$ \\
\hline
\end{tabular}

\section{Description of collected macrofungi}

\section{C. atramentarius (Bull.: Fr.) Fr.}

Description: Pileus 3-6 $\mathrm{cm}$ in diameter and oval when young, expanding to conical convex, up to 10 $\mathrm{cm}$ across; often with a curled up, lead gray, grayish or gray-brown, fairly smooth, but usually finely scaly to the center, faintly grooved. Stipe $8-15 \mathrm{~cm}$ long, 6$12 \mathrm{~mm}$ thick, equal, smooth or finely hairy, white, fibrous, hollow. Gills attached to the stem or free from it, whitish then becoming black, close or crowded. Spores 6.5-10.5 X 4-6.5 $\mu \mathrm{m}$, elliptical, smooth, with a central pore. Edible.

Collection examined: Uttar Pradesh, Gorakhpur district, Campierganj Tehsil, Campierganj block, Veer Bahadur Singh Park. Ravinder Pal Singh, DDUNPL-353, 14/07/14.

Specimen examined: Macroscopic and microscopic features agree well with the description given by Vishwakarmaet al, (2014).

\section{Coprinus comatus (O.F. Müll.) Pers.}

Description: Pileus $2-5 \mathrm{~cm}$ in diameter, oval to rounded cylindrical, at maturity expands to bell shaped with lifting margin, whitish with brownish center, with large shaggy scales, margin lined at maturity, turns to black ink at maturity. Stipe $3-5 \mathrm{~cm}$ long, 0.5-1 cm thick, tapering toward apex, smooth, white, easily separable with age, hollow, with a string like strand of fibres hanging inside. Gills free, white, black with age, crowded. Spores 10-12 X 8-9 $\mu \mathrm{m}$, elliptical, smooth. Flesh white, soft. Spore print black. Inedible.

Collection examined: Uttar Pradesh, Gorakhpur district, Sadar Tehsil, Khorabar block, Kushmi jungle. Ravinder Pal Singh, DDUNPL-345, 5/01/15. Specimen examined: Macroscopic and microscopic features agree well with the description given by Vishwakarmaet al. (2011). 


\section{C. congregatus Bull.: Fr.}

Description: Pileus $0.5-2 \mathrm{~cm}$ in diameter, pallid ochraceous-buff, with grayish tinge at the margin and usually slightly darker buff or fulvous towards the centre, at first ovoid and then bell-shaped or conical, deeply sulcate to the centre. Flesh thin, fragile and not auto-digesting. Stipe $5-8 \mathrm{~cm}$ long and $0.1-0.4 \mathrm{~cm}$ thick, white, smooth, slender, often slightly rooting. Ring absent. Flesh thin and fragile. Gills cream, becoming vinaceous-brown and finally black, adnate and crowded. Spores dark brown, smooth, ellipsoid or almond shaped, 12-14 X 6-7 $\mu \mathrm{m}$. Inedible.

Collection examined: Uttar Pradesh, Gorakhpur district, Campierganj Tehsil, Campierganj block, Veer Bahadur Singh Park. Ravinder Pal Singh, DDUNPL-356, 22/08/15.

Specimen examined: Macroscopic and microscopic features agree well with the description given by Prydiuk (2010).

\section{C. disseminates (Pers.: Fries) J.E. Lange}

Description: Pileus $0.5-1 \mathrm{~cm}$ in diameter, clay brown with dark colour tinge at center, ovoid, margin incurved, flesh thin, fragile, delicate. Stipe $1-2 \mathrm{~cm}$ long and 0.1-0.2 cm thick, hollow, delicate, fragile, white, minutely downy, ring absent. Gills white when young, at maturity changes to black, adnate, crowded. Spore print black. Spores 6-10 X 4-5 $\mu \mathrm{m}$. Inedible.

Collection examined: Uttar Pradesh, Gorakhpur district, Bansgaon Tehsil, Bansgaon block, Devkali village. Ravinder Pal Singh, DDUNPL-346, 22/08/15.

Specimen examined: Macroscopic and microscopic features agree well with the description given by Rawatet al. (2014).

\section{C. domesticus (Bolton) Gray}

Description: Pileus $1-5 \mathrm{~cm}$ in diameter, oval when young, expanding to convex, honey yellow and whitish toward the margin when young, becoming grey with brownish centre at maturity, covered with whitish universal veil fragment in the form of small scales or granules. Stipe $3-8 \mathrm{~cm}$ long, up to $1 \mathrm{~cm}$ thick, more or less equal, with a slightly swollen base, smooth, white, hollow, sometime with volva like rim at the base. Gills free, whitish at first, blackish with age, close. Spores 7-8 X 4.6-4.9 $\mu \mathrm{m}$, elliptical, smooth. Spore print black. Flesh thin, fragile. Inedible.

Collection examined: Uttar Pradesh, Gorakhpur district, Bansgaon Tehsil, Bansgaon block, Devkali village. Ravinder Pal Singh, DDUNPL-347, 12/08/15.
Specimen examined: Macroscopic and microscopic features agree well with the description given by Anand et al. (2014).

\section{C. extinctorius (Bull.) Fr.}

Description: Pileus $1.5-2.5 \mathrm{~cm}$ in diameter, pallid ochraceous-buff, darker and more tawny towards the centre; at first ovoid, then bell-shaped or conical, finally flattened with strongly reflexed margin, deeply sulcate as far as the centre, covered with small, pointed, fibrous scales, becoming smoother. Flesh whitish at first thin, fragile, and auto-digesting. Stipe $3-11 \mathrm{~cm}$ tall and $0.4-0.6 \mathrm{~cm}$ thick, white, slender, more or less equal or tapering slightly upwards, at first pruinose at apex, then smooth, downy at base. Ring absent. Flesh whitish and fragile. Gills white, then grayish-brown and finally black, adnexed, crowded. Spores dark brown, smooth, almond shaped, germ pore, 8-10 X 6.5-7.5 $\mu \mathrm{m}$. Inedible.

Collection examined: Uttar Pradesh, Gorakhpur district, Bansgaon Tehsil, Bansgaon block, Devkali village. Ravinder Pal Singh, DDUNPL-354, 12/08/14.

Specimen examined: Macroscopic and microscopic features agree well with the description given by Gehlotet al. (2014).

\section{C. hemerobius Fr.}

Description: Pileus $1-1.5 \mathrm{~cm}$ in diameter, ochraceous or pallid leather, becoming grey at maturity, at first ovoid and then campanulate and finally flattened, deeply sulcate as far as the centre, otherwise more or less smooth, without velar remnants. Flesh pallid, thin, fragile and auto-digesting. Stipe $3-6 \mathrm{~cm}$ tall and 0.1-0.2 cm thick, whitish-cream, very slender, more or less equal, smooth. Ring absent. Flesh pallid and fragile. Gills buff, then grayish-brown, adnexed or free, close. Spores dark brown, smooth, ellipsoid or almond-shaped, germ pore, 11.5-12.5 X 6-8 $\mu \mathrm{m}$. Inedible.

Collection examined: Uttar Pradesh, Gorakhpur district, Sahjanwan Tehsil, Sahjanwa block, Sahijana village. Ravinder Pal Singh, DDUNPL-348, 25/08/15.

Specimen examined: Macroscopic and microscopic features agree well with the description given by Nagy et al. (2010)

\section{C. heterosetulosus Locq. ex Watling}

Description: Pileus at first $0.5-1 \mathrm{~cm}$ in diameter, ovoid, ellipsoid to elongate-ellipsoid, then campanulate to convex, finally applanate, slightly ribbed, brown, greyish brown to dark brown, becoming paler towards margin, up to light brown, then grey, brown at centre. Lamellae free or almost free, at first whitish then blackish-brown, finally nearly black. Stipe $1.5-4.5 \mathrm{~cm}$ long and $0.3-0.8 \mathrm{~mm}$ thick, cylindrical with somewhat clavate base, 
whitish, hyaline, minutely pubescent. Flesh thin, whitish. Spore print black. Spores 8.5-11.5 X 5.0-6.5 $\mu \mathrm{m}$, ovoid, ellipsoid-ovoid or ellipsoid and apex rounded, germ pore eccentric. Inedible.

Collection examined: Uttar Pradesh, Gorakhpur district, Campierganj Tehsil, Campierganj block, Veer Bahadur Singh Park. Ravinder Pal Singh, DDUNPL-349, 22/08/14.

Specimen examined: Macroscopic and microscopic features agree well with the description given by Prydiuk (2010).

\section{C. impatiens (Fr.) Quél.}

Description: Pileus 1-3 cm in diameter, pallid buff, tawny or cinnamon towards the centre, drying more pallid, at first ovoid, then conical-convex and finally flattened, markedly sulcate as far as the centre. Flesh whitish, thin, fragile and auto-digesting. Stipe 7-9 cm tall and $0.2-0.4 \mathrm{~cm}$ in diameter, whitish, very slender, more or less equal, at first minutely pruinose, then smooth, silky. Ring absent. Flesh whitish and fragile. Gills buff, then grayish-brown, adnexed or free, distant. Spore 9-12 X 5-6 $\mu \mathrm{m}$, dark brown, smooth, ellipsoid or almond shaped, germ pore. Inedible.

Collection examined: Uttar Pradesh, Gorakhpur district, Bansgaon Tehsil, Bansgaon block, Devkali village. Ravinder Pal Singh, DDUNPL-358, 22/08/15.

Specimen examined: Macroscopic and microscopic features agree well with the description given by Jordan (1995).

\section{C. lagopus (Fr.) Fr.}

Description: Pileus $1-3 \mathrm{~cm}$ in diameter, oval when young, fully expand to flat at maturity, gray to black, at first covered with a dense coating of silvery hairs which break up into patches as the macrofungi matures, may eventually disappear, the finely lined margin splitting as the gills dissolves. Stipe $1-2 \mathrm{~cm}$ long and $0.5 \mathrm{~cm}$ thick, more or less equal, cylindrical, hollow, fragile, white, densely hairy at first, becomes smooth with maturity. Gills attached with stem, crowded, pale at first becomes black at maturity. Spores 12-13 X 7-8 $\mu \mathrm{m}$, elliptical, smooth. Spore print black. Flesh weak, fragile, soft. Inedible.

Collection examined: Uttar Pradesh, Gorakhpur district, Bansgaon Tehsil, Bansgaon block, Dugauli village. Ravinder Pal Singh, DDUNPL-355, 22/08/15.

Specimen examined: Macroscopic and microscopic features agree well with the description given by Kakde and Gaikwad (2014).

\section{C. leiocephalus P Orton}

Description: Pileus $0.5-1.5 \mathrm{~cm}$ in diameter, reddishbrown, becoming grey at maturity, darker at the centre, at first ovoid, then conical-convex and finally flattened, markedly sulcate as far as centre, otherwise more or less smooth, without velar remnants, Flesh pallid, thin, fragile and auto-digesting. Stipe $5-9 \mathrm{~cm}$ tall and 0.1-0.2 cm thick, whitish-cream becoming tinged brown, very slender, more or less equal, smooth. Ring absent. Flesh pallid and tinged. Gills buff, then grayish-brown, adnexed or free, close. Spores dark brown, smooth, ellipsoid or almondshaped, germ pore, 8-11 X 5.5-8.5 $\mu \mathrm{m}$. Inedible.

Collection examined: Uttar Pradesh, Gorakhpur district, Bansgaon Tehsil, Bansgaon block, Dugauli village. Ravinder Pal Singh, DDUNPL-350, 25/08/15.

Specimen examined: Macroscopic and microscopic features agree well with the description given by Nagy et al. (2010).

\section{C. micaceus Bull.: Fr.}

Description: Pileus2-15 cm, oval when young, expanding to broadly convex or bell-shaped, sometimes with a curled up, honey brown, tawny, amber, or sometimes paler, becoming paler with age, especially towards the margin, buttons covered with mica-like granules which frequently wash off with rain or dew, the margin lined or grooved, usually halfway towards the center or more. Stipe $2-8 \mathrm{~cm}$ long, 3-6 mm thick, equal, smooth to very finely hairy or granulated, white, fibrous, hollow. Gills attached to the stem or free from it, pale, becoming brown then black, deliquescing (turning to black "ink"), close or crowded. Spores 7-11 X 4-7 $\mu$ m, subelliptical to mitriform, smooth, with a central pore. Inedible.

Collection examined: Uttar Pradesh, Gorakhpur district, Bansgaon Tehsil, Bansgaon block, Dugauli village. Ravinder Pal Singh, DDUNPL-352, 22/07/14.

Specimen examined: Macroscopic and microscopic features agree well with the description given by Keirleet al. (2004).

\section{C. radiates (Bolt.: Fr.) S F Gray}

Description: Pileus $0.2-0.8 \mathrm{~cm}$ in diameter, at first white, shaggy with velar remnants which fall away, then soot-grey, at first ovoid or cylindrical becoming campanulate-expanded, sulcate. Flesh very thin and fragile, limited auto-digesting. Stipe $2-3 \mathrm{~cm}$ tall and 0.1-0.2 cm thick, white or buff. Ring absent. Flesh brittle and very delicate. Gills pallid clay, sometimes with pinkish tinge, soon grey and finally black, distant, free. Spores black, smooth, ellipsoid, 11-12.5 X 6.5-7.5 $\mu \mathrm{m}$. Inedible.

Collection examined: Uttar Pradesh, Gorakhpur district, ChauriChauraTehsil, Sardar Nagar block, 
KewlaChowk village. Ravinder Pal Singh, DDUNPL-351, 12/08/15.

Specimen examined: Macroscopic and microscopic features agree well with the description given by Prydiuk (2011).

\section{C. truncorum (Scop.) Fr.}

Description: Pileus 1.5-2.5 cm diameter, deep creamy buff, covered with white mealy granules, wrinkled striate except at the centre, subglobose, expanding to conical or convex. Stipe $4-8 \mathrm{~cm}$ long, $0.2-0.5 \mathrm{~cm}$ thick, cylindrical, hollow, delicate white. Gills free, white at first becoming black with maturity, parallel, narrow. Spores 6-7.5 X 5.5-6 $\mu \mathrm{m}$, spherical. Spore print blackish brown. Flesh delicate, thin, soft. Inedible.

Collection examined: Uttar Pradesh, Gorakhpur district, Bansgaon Tehsil, Bansgaon block, Dugauli village. Ravinder Pal Singh, DDUNPL-357, 22/08/15.

Specimen examined: Macroscopic and microscopic features agree well with the description given by Keirleet al. (2004).
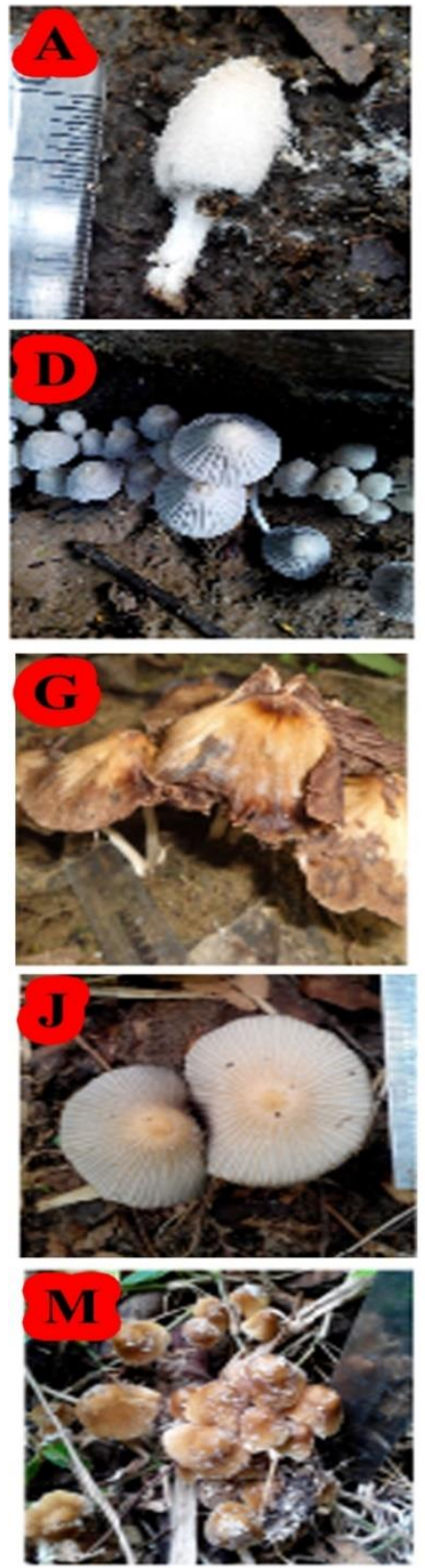
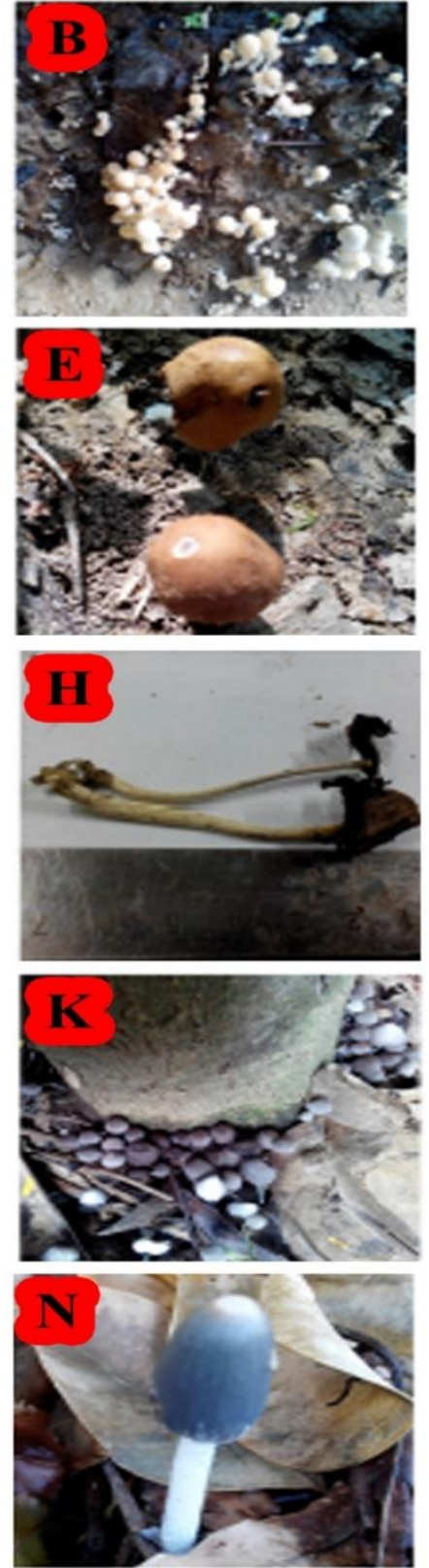
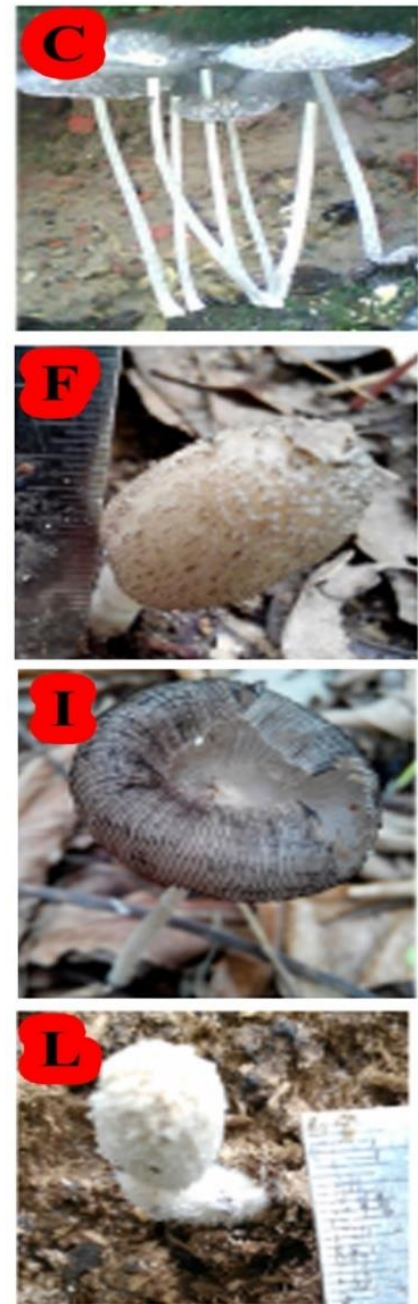

Fig.1 A. Coprinus comatus, B-C. disseminates, C-C. domesticus, D-C. lagopus, E-C. truncorum, F-C. heterosetulosus, GC. atramentarius, $\mathbf{H}-C$. congregates, $\mathbf{I}-C$. extinctorius, J-C. hemerobius, $\mathbf{K}-C$. leiocephalus, $\mathbf{L}-C$. radiatus, $\mathbf{M}-C$. micaceus, $\mathbf{N}-$ C. impatiens 


\section{Discussion}

Species diversity of macrofungi is related to their particular habitats. The factors like geographic location, elevation, temperature, humidity, light and surrounding flora greatly influence the growth and developmentof macrofungi (Tapwalet al., 2013). In present study 14 Coprinus species were collected from different parts of Gorakhpur district during 20142016. Several reports on higher fungi had been made from Northern India which includes North Western region, Eastern Himalaya proper and North Eastern hilly areas. North Western region of India includes Punjab, Haryana, Chandigarh and Gujarat while the Eastern Himalaya proper includes the Northern parts of Assam, the whole of Arunachal Pradesh and Sikkim and North-Eastern covers the hilly states of Nagaland, Meghalaya, Manipur, Mizoram and Tripura (Thatoi and Singdevsachan, 2014).

From time to time different workers had studied macrofungal diversity of different parts in India. Kumar and Sharma (2009) found Coprinus comatus from Jammu and Kashmir while Vishwakarma et al. (2011) also reported Coprinus comatus form Garhwal, Uttrakhand. Other workers Rawatet al. (2014) reported Coprinus disseminates from Pithoragarh, Uttrakhand. Coprinus atramentarius, $C$. auricomus, $C$. domesticus, C. picaceus reported by Anand et al. (2014) from Rajouri district, Jammu and Kashmir while Prydiuk, (2010) reported 8 Coprinus species viz., C. miser, C. bisporus, C. brevisetulosus, C. congregates, $C$. curtus, C. ephemerus, C. heterosetulosus and C. pellucidus from Ukraine.

\section{Conclusion}

The present study thus illustrates the unexplored biodiversity of macrofungi from Gorakhpur district (U.P.). The taxonomical identification was performed as per the genus and species. Socioeconomic and pharmacological importance was examined as per the local and tribal communities of the forests residing in the district. As per the present investigation, it is believed that few more surveys can explore some other new species which are still unrevealed and not reported previously. The noteworthy outcome of the present study was the occurrence of fourteen species of Coprinus which economically important mushroom are. There is a vast scope for documentation of macrofungi from this region in future.

\section{Acknowledgements}

The authors thank to the Head, Department of Botany, DDU Gorakhpur University, Gorakhpur, for providing necessary laboratory facilities. Ravinder Pal Singh is also thankful to UGC New Delhi for Rajiv Gandhi National Fellowship.

\section{References}

1. Anand N., Mathur A., Chowdhary P. N. (2014). First report on Survey of macro fungal biodiversity in Rajouri Dist. (J\&K), India. World Journal of Pharmacy and Pharmaceutical Sciences. 3(12): 1385-1402.

2. Borkar P., Doshi A. and Navathe S. (2015). Mushroom diversity of Konkan region of Maharashtra, India. Journal of Threatened Taxa. 7(10): 7625-7640.

3. Chandrawati, Singh P., Kumar N, Tripathi N.N. (2014). Macrofungal wealth of Kusumhi forest of Gorakhpur, UP, India. American International Journal of Research in Formal, Applied \& Natural Sciences. 5(1): 71-75.

4. Das K. (2010). Diversity and conservation of wild mushrooms in Sikkim with special reference to Barsey Rhododendron Sanctuary. NeBIO 1(2): 1-13.

5. Dutta A. K., Chakraborty N., Pradhan P. and Acharya K. (2012). Phallales of West Bengal, India. II. Phallaceae: Phallus and Mutinus. Researcher. 4(8): 21-25.

6. Gehlot P., Sharma R. and Sharma K. (2014). Diversity of wild mushroom flora from Indian Thar Desert. $8^{\text {th }}$ International Conference on Mushroom Biology and Mushroom Products. 92-97.

7. Jordan, M. 1995. The Encyclopedia of fungi of Britain and Europe, John Taylor Book Venture Ltd., Newton Abbbot, Devon.

8. Kakde R. B. and Gaikwad R. S. (2014). Diversity of wood decay fungi at Mantha, Jalna (MS) India. Bioscience Discovery. 5(2): 230-236.

9. Kaya A., Uzun Y., Keleş A., Demirel K. (2010). Three coprinoidmacrofungi taxa, new to Turkey. Turk J Bot. 34: 351-354.

10. Keirle M. R., Hemmes D. E. and Desjardin D. E. (2004). Agaricales of the Hawaiian Islands. 8. Agaricaceae: Coprinus and Podaxis; Psathyrellaceae: Coprinopsis, Coprinellus and Parasola. Fungal Diversity 15: 33-124.

11. Nagy G. L., Vágvölgyi C. and Papp T. (2010). Type studies and nomenclatural revisions in Parasola (Psathyrellaceae) and related taxa. Mycotaxon. 112: 103-141.

12. Prydiuk M. P. (2010). New records of dunginhabiting Coprinusspecies in Ukraine I. Section Pseudocoprinus. Czech Mycol. 62(1): 43-58. 
13. Rawat S., Adhikari R. S. and Tiwari A. (2014). Higher Fungi Associated with Decomposing Leaf Litter of Pinuslongifolia. Int.J.Curr.Microbiol.App.Sci. 3(10):722-732.

14. Vishwakarma M. P., Bhatt R. P. and Gairola S. (2011). some medicinal mushroom of GarhwalHimalya, Uttrakhand, India. Int. J. Med. Arom. Plant5. 1(1): 33-40.

15. Vishwakarma P., Singh P., Mishra P. and Tripathi N. N. (2014). Diversity of Some Wild Mushroom from Gorakhpur, Uttar Pradesh, India. Int. J. of Pharm. Life Sci. 5(7): 3643-3647.
16. Vishwakarma P., Singh P., and Tripathi N. N. (2017). Biodiversity of Macrofungi with special reference to edible forms: A review. J. Indian bot. Soc. 96(3\&4): 144-187.

\section{Cite this article as:}

Ravinder Pal Singh, Aradhana Pal, Pooja Singh and N. N. Tripathi. Diversity of Coprinus species in North-Eastern part of Uttar Pradesh, India. Annals of Plant Sciences 7.5 (2018) pp. 2282-2288.

do $\mathrm{http://dx.doi.org/10.21746/aps.2018.7.5.12}$

Source of support: U.G.C., New Delhi, India.

Conflict of interest: Nil 